\title{
Monika KONSTANTINOV SLAVOLOK OSVALD IN ZATON RIMSKEGA CESARSKEGA KULTA
}

\section{Izvleček}

Čeprav je Konstantin Veliki izvojeval odločujočo bitko pri Milvijskem mostu v znamenju križa, se na številnih kasnejših spomenikih prepletati poganska solarna in krščanska ikonografija. Posamezni prizori Konstantinovega slavoloka tako omogočajo večplastno branje, ki je zadovoljilo tako poganskega kot krščanskega gledalca. Obenem jasno pokažejo na značaj premen cesarskega kulta: poganske honores so resda ukinjene, toda cesar in vse, kar je $z$ njim povezano, ostaja sveto in božansko.
Abstract

Although Constantine the Great fouhgt at the decisive battle of Milvius Bridge under the sign of the cross, on many later monuments, pagan and Christian iconography is interwined. Individual scenes of Constantine's triumphal arch can be interpreted in different ways that satisfy both pagan and Christian observers. They show both according to characteristics of the ruler cult pagan honores are abolished but emperor and all associated with him remane holy and god-like.

Prvi del:

RAZVOJ KULTA VLADARJA PO AVGUSTU IN NJEGOVE PREMENE S KONSTANTINOM VELIKIM

\section{Kult cesarja v času principata}

Religiozno-filozofski in pravni temelji apoteoze so bili vzpostavljeni z Julijem Cezarjem; izpopolnjena forma državnega kulta cesarja tako za časa življenja kot po smrti se je izoblikovala z Avgustom. Honores, ceremonial, nove insignije, ikonografija spomenikov in urbanistične podobe mesta ter vse ostalo, kar je spadalo v ta okvir, je bilo v avgustejski dobi natančno izbrano in določeno ter je predstavljalo vsebinsko-formalne okvire držav- 
nega kulta cesarja v kasnejših obdobjih. S posameznimi cesarji je sicer prihajalo do sprva manjših, od 3. stoletja dalje ter kasneje s Konstantinom izrazitih vsebinskih sprememb, toda avgustejska formula je ohranila veljavo in pojavno obliko vse do konca rimskega imperija. Emile Beurlier ${ }^{1}$ jo povzema takole:

(a) za časa življenja:

- čaščenje cesarja kot boga na vzhodu (tempelj; duhovnik archiereus) ter kult cesarjevega genija (žrtvovanja in prisega pri geniju) v Rimu (oltar; pontifices s cesarjem kot pontifexom maximom na čelu), municipijih (tempelj na forumu; flamines ali sacerdotes Augustales) in zahodnih provincah (oltar; flamen ali sacerdos province);

- poimenovanje mesecev;

- podoba cesarja inter simulacra deorum, zlasti med igrami v cirkusu;

- cesarjev zlati (ali krizelefantinski) prestol in krona med prestoli bogov na prizorišču teatralnih iger;

- herojski portreti, portreti s cesarskimi insignijami, konjeniški spomeniki (na konju ali na kvadrigi); inspirirana in transfigurirana podoba (identifikacija z bogovi);

- cesarske insignije kot znamenja oblasti; ${ }^{2}$

- adoratio v obliki proskineze od Dioklecijana dalje.

(b) po smrti:

- uradna konsekracija: pogrebni ceremonial in sklep senata (senatus consultum) o divinizaciji cesarja;

- templji in oltarji, posvečeni božanskemu cesarju ( $v$ Rimu, municipijih, vzhodnih in zahodnih provincah); flamen Divi Augusti in kolegij duhovnikov sodales Augustales;

- različni festivali (zlasti natales ob cesarjevem rojstvu in ob rojstvu njegove moči);

- imena božanskih cesarjev med imeni ostalih bogov v molitvah;

BEURLIER, 1891, str. 204 - 205.

2 Cesarske insignije (kot znamenja cesarske oblasti) so se v teku rimskega imperija spreminjale in s svojo dokončno obliko (dovršeno v času Dioklecijana-Konstantina) vplivale na srednjeveške in bizantinske cesarske reprezentacije. Pogojno moremo postaviti naslednjo tipologijo:

(1) insignije novega oz. avgustejskega tipa: lovorjevi drevesi, hrastova krona, Viktorija s klipejem virtutis;

(2) tradicionalno-monarhične insignije (Jupitrovi atributi): krona, strela ali žezlo, sphaera kot oikoumene (Dion Kasij, XLIII, 14,6), orel;

(3) insignije zmagoslavja: Viktorija stefanefora ali orel stefanefor kot prostostoječa ali na žezlu oz. sphaeri;

(4) Sončeve insignije: (a) tip Sol: žarkasta krona; (b) tip Sol Invictus: magična desnica in globus; (c) dokončna oblika v času Dioklecijana-Konstantina: diadem, pozlačena oblačila, nimb, avreola. 
- podobe konsekriranih cesarjev se ne zvrstijo v sprevodu znamenitih Rimljanov ob slavnostnih pogrebih.

Od posameznega cesarja je bilo odvisno, koliko časti je zahteval zase za časa življenja, od njegovega naslednika oz. tedanje politične situacije njegov status po smrti. Tako so bili Kaligula, Domicijan in Komodij čaščeni po božje že za časa življenja, toda med temi tremi je status božanskega cesarja po smrti dosegel le Komodij. Klavdij svojega predhodnika ni konsekriral, Domicijana je doletela celo damnatio memoriae. Čeprav je bil kulta vladarja za časa življenja v bolj ali manj zmerni obliki deležen vsak rimski cesar, pa to ne velja za konsekracijo po smrti. Med Julijci so bili po smrti uradno sprejeti med bogove le Julij Cezar, Avgust in Klavdij; med Flavijci Vespazijan in Tit; od Antoninov dalje je postala konsekracija, razen izjem, obvezna praksa, ki se je razširila tudi na izbrane družinske člane. Pravni akt poganske konsekracije se je ohranil tudi v času krščanstva vse do Valentinijana III. ${ }^{3}$

\section{Preoblikovanje kulta cesarja v času Dioklecijana in Konstantina Velikega}

Dioklecijan (284 - 305) je bistveno spremenil sistem rimske cesarske oblasti. Opustil je Avgustov principat in uvedel dominat. Poimenovanje nove oblike vladavine tudi tokrat izhaja iz uradnega cesarjevega naziva, ki se glasi dominus et deus. Že prej, v času principata, so si nekateri cesarji prevzeli naziv dominus: najprej Kaligula; ${ }^{4}$ Vespazijan je na novcih imenovan $\mathrm{z}$ odgovarjajočim grškim kyrios; Domicijana so morali nazivati z dominus et deus, ${ }^{5}$ Antonin Pij je na napisih dominus ali princeps; naziv dominus et deus so nosili tudi vojaški cesarji Avrelijan, Prob in Kar. Toda v času principata je šlo bodisi za omejene poskuse ekstremističnih cesarjev bodisi za gole nazive, ki niso zahtevali vsebinskih sprememb. Nasprotno je bilo v času Dioklecijana novo poimenovanje vladarja odsev spremenjene oblike vladavine in obenem novega statusa cesarja.

V Trajanovi dobi je Plinij ml. ${ }^{6}$ zapisal, da se principat in dominat po obliki vladanja medsebojno izključujeta: »Scio sunt diversa natura dominatio et principatus. « Dioklecijanov dominat je monarhija vzhodnega tipa v polnem pomenu besede; prevzel je tudi orientalni dvorni ceremonial in insignije. Dioklecijan je bil tako po pričevanju Avrelija Viktorja in Evtropija prvi rimski cesar, ki je namesto običajne salutatio zahteval adoratio (proskinezo) ${ }^{7}$ Verjetno je tudi prvi uvedel prakso cesarjevega umika iz vsakdanje-

3 BEURLIER, 1891, str. 205.

4 Svetonij, Kaligula, 9, 34: »dominum se iussit appellari»

5 Svetonij, Domicijan, 13, 2; Dion Kasij, LVVII, 4, 7

"Plinij ml., Panegirik, 45

7 Avrelij Viktor, Caesares, XXXIX, 2, 4; Evtropij, IX, 26: »qui imperio Romano primus 
ga javnega življenja: vladar se je odslej v javnosti pojavil le redko, v okviru izoblikovanega ceremoniala cesarske aparitio, oblečen v slavnostna oblačila, posuta z zlatim prahom in z zlatim diademom na glavi (zlato oblačilo in diadem je Dioklecijan prevzel od Avrelijana). Cesar je bil tako obdan z avro svetosti.

Ker se je Dioklecijan zavedal, da obsežnega območja rimskega imperija, zlasti zaradi nestabilnih meja, ne more obvladati sam, je poleg dominata uvedel tetrahijo ali vlado štirih. Imperij je bil tako v upravnem smislu razdeljen na vzhodni in zahodni del; vsaki polovici je vladal po en avgust in vsak si je izbral še po enega pomočnika, imenovanega cesarja, ki naj bi ga kasneje nasledil. Prvo tetrarhijo so sestavljali avgusta Dioklecijan in Maksimijan ter cesarja Galerij in Konstancij Hlor. Tetrarhija je bila sicer vlada štirih, toda vladajoči subjekti si niso bili po pristojnostih enakopravni: avgusta sta bila po statusu višje od cesarjev, toda med njima je nadvladal tisti, ki je vodil vzhodni del imperija. Na to kaže tudi poimenovanje: Dioklecijan je nosil nadimek Iovius, Maksimijan Herculius. ${ }^{8}$

Obenem sta bila »Jupiter in Herkul njuna spremljevalca (comites) in zaščitnika (conservatores). Dioklecijan je bil deležen najvišjega statusa po božanski investituri; nalogo, da vlada nad svetom, je namreč prejel od Jupitra. 'Od zgoraj' mu je bila dana tudi možnost, da postavi druge imperatorje, ki bi delili z njim odgovornost vladanja. «"

S Konstantinom (306 - 337), sinom tetrarha Konstancija Hlora in njegove prve žene Helene, so zlasti na religioznem področju nastopile bistvene spremembe, ki so odločujoče vplivale na pozno antično dobo in na kasnejši potek zgodovine. Po bitki pri Milvijskem mostu letu 312, kjer je Konstantin po videnju in preroških sanjah ${ }^{10}$ dosegel zmago nad Maksenci-

regiae consuetudinis formam magis quam Romanae libertatis invexerit adorarique se iusserit, cum ante eum cuncti salutarentur"

8 Laktancij, De morte persecutorum, 52, 3: "magnifica illa et clara per gentes Ioviorum et Herculiorum cognomina, quae primum a Dioclete et Maximiano insolenter adsumpta ac postmodum ad successores eorum translata viguerunt"

9 MARCONE, 2000, str. 9.

10 O Konstantinovem videnju znamenja križa nad Soncem in preroških sanjah poročata Evzebij (Vita Constantini, I, 28,2 - 30) in Laktancij (De morte persecutorum, 44). Evzebijevo pričevanje se v prostem prevodu glasi takole: "Trdil je, da je ob uri, ko je Sonce na polovici svoje poti, ko dan komaj začne upadati, videl na lastne oči, ob jasnem nebu, preko Sonca sijoče znamenje križa in ob njem napis: HOC SIGNO VINCES. Zaradi tega videnja se je njega in njegove vojske polastil nemir. (...) Medtem ko je vneto premišljeval o dogodku, je padla noč. Tedaj se mu je v sanjah prikazal Kristus, Božji sin, z znamenjem, ki se je pokazalo na nebu, in mu naročil, naj izoblikuje podobo, slično tej, ki jo je videl na nebu, in naj se je posluži kot zaščite v boju proti sovražnikom. Takoj po sončnem vzhodu je vstal in zaupal sanje prijateljem. Potem je sklical zlatarje in mojstre, ki so bili vešči dela z dragimi kamni, se usedel mednje, opisal znamenje in jim naročil, naj ga izdelajo v zlatu in dragocenih kamnih.« 
jem 'v znamenju križa', ${ }^{11}$ sta leta 313 skupaj z Licinijem izdala v Milanu tolerančni edikt. S tem ediktom je bilo konec preganjanj kristjanov, ki so dosegla največjo intenzivnost na vzhodu v času tetrarhov. Milanski edikt se, citiran po Evzebiju, ${ }^{12}$ v latinskem prevodu glasi: »... cum feliciter tam ego Constantinus Augustus quam etiam ego Licinius Augustus apud Mediolanum convenissemus ... in primis ordianda esse credidimus quibus divinitatis reverentia continebatur ut daremus et Christianis et omnibus liberam potestatem sequendi religionem quam quisque voluisset«.

O vprašanju Konstantinove spreobrnitve je bilo veliko napisanega. Mnenja in stališča piscev se močno razlikujejo: nekateri so mnenja, da je šlo za preračunljivo izbiro, s katero bi si cesar pridobil na svojo stran kristjane (toda ti so bili v začetku 4. stoletja izrazito v manjšini); drugi, da je Konstantin praznoverno verjel v krščansko znamenje križa kot v fetiš... do diametralno nasprotnega stališča, da je Konstantin zavestno sprejel krščansko vero. Zadnje študije ${ }^{13}$ se nagibajo v prid slednji trditvi, toda obenem poudarjajo, da ni šlo za nenadno spreobrnitev po preroških sanjah, ampak za dolgotrajen proces, osnovan na dejstvu, da je bil Konstantin vnet častilec boga Nepremagljivega Sonca.

Arnaldo Marcone $e^{14}$ stopi še korak nazaj in pravi, da je bil »Konstantinov prvi preobrat že $v$ tem, da je $v$ nasprotju $z$ Dioklecijanom in tetrarhi spodbujal čaščenje enega samega, vrhovnega boga, ki je bil spočetka Sol Invictus. Kolegij štirih cesarjev je predvideval pluralnost bogov-zaščitnikov; ponovna monarhična rešitev pa je dajala prednost enemu samemu božanstvu kot zaščitniku edinega vladarja."

$\mathrm{Z}$ videnjem, preroškimi sanjami in po zmagi nad Maksencijem leta 312 se je začel proces pokristjanjanja Konstantina in z njim celotnega rimskega imperija. Toda prvo obdobje Konstantinovega krščanstva je bilo v znamenju sinkretizma. Svoje najvišje božanstvo je počasi poistovetil s krščanskim Bogom, kasneje pa je vedno bolj poudarjal, da je 'služabnik' božanske moči, ki jo časti krščanska Cerkev in v imenu katere je zmagal vse svoje najpomembnejše bitke.

Konstantinov sprejem krščanske vere je nujno vplival na kult vladarja. Uradni cesarski kult je v obliki poganskih honores postopoma ukinil, kajti cesar se ni mogel več identificirati $\mathrm{z}$ božanstvom ali postati po smrti on sam bog. Toda glede dojemanja in posledično čaščenja cesarjeve osebnosti (bodisi glede cesarjevega lastnega mnenja o samem sebi bodisi glede

${ }^{11}$ Laktancij, De morte persecutorum, 44: »Commonitus est in quiete Constantinus, ut caeleste signum dei notaret in scutis atque ita proelium committeret. Fecit ut iussus est et traversa $X$ littera, summo capite circumflexo, Christum in scutis notat. Quo signo armatus exercitum capit ferrum. «

${ }^{12}$ Evzebij, Hist. Eccl., VIII, 17; podobno pri Laktanciju, De morte persecutorum, 33 - 34.

1: Novejša literatura zbrana v MARCONE, 2000, str. 115 - 118.

${ }^{14}$ MARCONE, 2000, str. 42. 
pojmovanja podanikov) se s prehodom iz poganstva v krščanstvo ni dovršila nobena bistvena sprememba. V lastnih očeh je bil Konstantin človek in vladar, ki ga je Najvišji oblastnik izbral, da bi se boril za 'Njegovo stvar'. Poganski pisci panegirikov, ki so navadno imenovali vladarja za boga na zemlji, so se sedaj zatekli v neoplatonični monoteizem, ki je prevladoval v izobraženih aristokratskih krogih. Eden izmed njih je zapisal: »Konstantin, gotovo imaš neko skrivno vez z božanskim Logosom, ki se razkriva le tebi samemu. « $^{15} \mathrm{Za}$ kristjane je Konstantin deloval v Božjem imenu in bil morda celo Božji posrednik na zemlji. V panegiriku ob priliki cesarjevih tricennalia je Evzebij iz Cezareje o Konstantinu zapisal: »Konstantin, Božji prijatelj, upravlja vse zemske zadeve v podobnosti z nebeškim kraljestvom. «" ${ }^{16}$

»Cesar in vse, kar je bilo z njim povezano, je ostalo sveto in božansko. Sprva se je nadaljevala celo uradna poganska oblika kulta cesarja, le v nekoliko 'očiščeni' obliki. Provincialni shodi so še vedno volili velike duhovnike, ki so v čast vladarja inavgurirali igre, in mu celo postavljali templje. Nenavaden dokaz je napis iz kraja Hispellum v Umbriji. Umbrijska mesta so namreč prosila za dovoljenje za izgradnjo lastnega templja na čast cesarja in za izvedbo teatralnih in gladiatorskih iger, ki naj bi jih inavguriral njihov lasten duhovnik. Konstantin je privolil pod edinim pogojem, naj ne bo tempelj pod njegovim imenom onečaščen s 'kužnim praznoverjem'.

Konstantin in njegovi nasledniki so še dve generaciji obdržali poganski naslov pontifex maximus, ki pa je bil del tradicionalnega imperialnega naziva in ni zahteval udeležbe pri poganskem obredju. ${ }^{17}$

Konstantin Veliki je bil po smrti konsekriran. Ceremonial pogreba in ikonografija upodobitev, ki so $\mathrm{v}$ različnih medijih prišle ob tej priliki 'v obtok' (zlasti novci in medaljoni, čeprav Evzebij poroča tudi o bolj reprezentativnih likovnih upodobitvah ${ }^{18}$ ), sta bila ambivalentna in sta tako omogočala dvojno razumevanje: za pogane se je cesar povzdignil ad sidera, za kristjane ga je Bog sprejel k sebi na nebo.

Po Konstantinu naj bi bili, po prepričanju Emila Beurliera, ${ }^{19}$ konsekrirani tudi nadaljnji cesarji, vse do Arkadija. Toda do Konstancija II. je divinizacija zanesljivo izpričana, kajti ohranjena sta novec, izdan ob konsekraciji Konstantina Velikega, in medaljon Konstancija II. s podobno motiviko. Za nadaljnje cesarje temelji hipoteza na manj zgovornih pisnih virih, kjer je izpričan le naziv DIVUS ob imenih posameznih cesarjev. ${ }^{20}$ Kateri pomenski okvir je divus prekrival, iz ohranjenega materiala ni moč razbrati, dejstvo pa je, da je to poimenovanje kmalu prešlo na svetnike krščanske Cerkve.

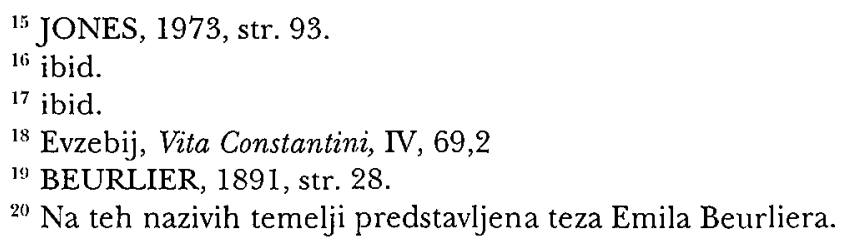


Ob vsem tem A.H.M. Jones zapiše: »Brez pretiravanj moremo trditi, da je bilo Konstantinovo pokristjanjenje bistvenega pomena za razvoj krščanstva. Po spreobrnitvi je Konstantin vladal še petindvajset let v 'zmagoslavju in izobilju' ter zapustil cesarstvo svojim trem sinovom, ki so bili vzgojeni v krščanski veri in med katerimi je zadnji vladal še nadaljnjih štiriindvajset let. V pol stoletja je tako krščanstvo postalo vodilna religija v cesarstvu in Julijanov poskus ponovne uvedbe poganstva bi bil vseeno obsojen na propad, čeprav ta ne bi umrl po osemnajstih mesecih vladanja. Toda, v primeru, da ne bi prišlo do Konstantinove spreobrnitve, bi krščanstvo morda ostalo minorna sekta, kot se je kasneje dogodilo v sosednjem perzijskem imperiju, kjer se ni noben kralj ${ }^{21}$ spreobrnil in kjer so kristjani, kot prej v poganskem rimskem imperiju, živeli dolga obdobja tolerance s krajšimi presledki preganjanj.«"22

Drugi del:

KONSTANTINOV SLAVOLOK V RIMU

Troločni Konstantinov slavolok so postavili na začetek rimske Via

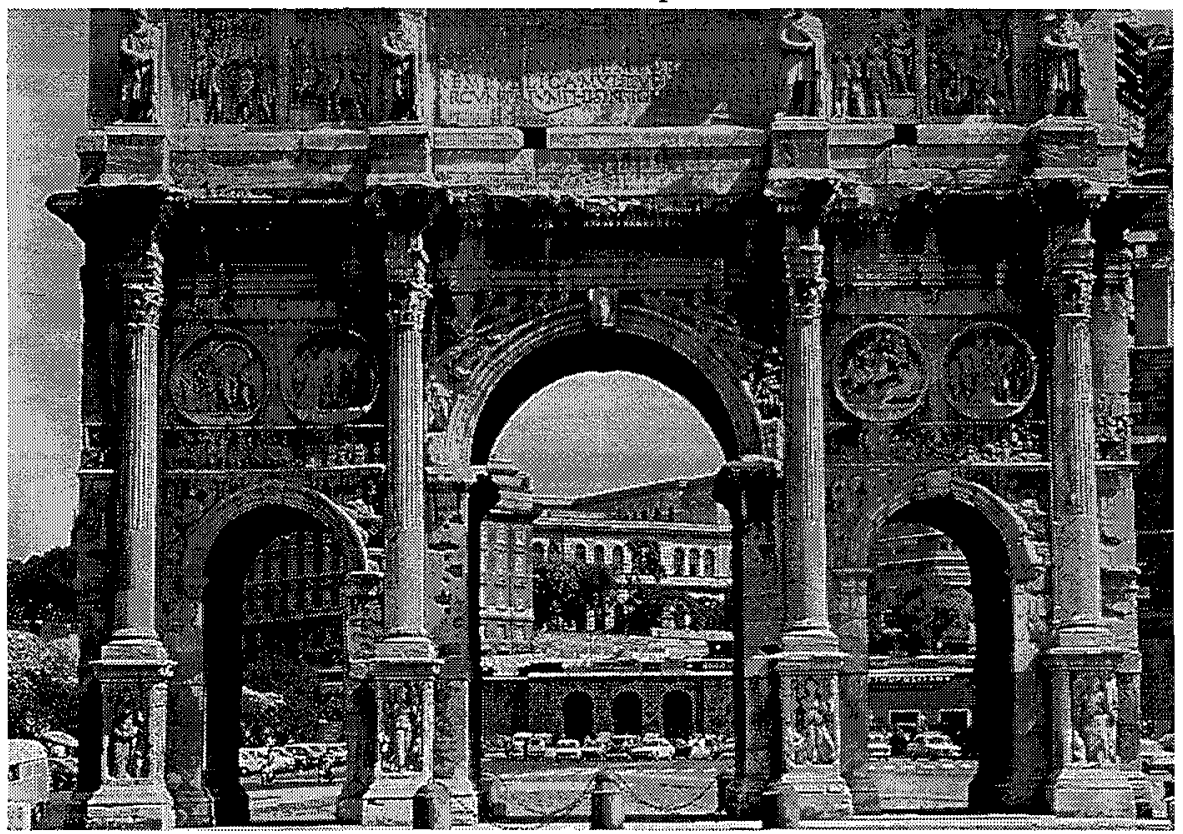

Slika 1: Konstantinov slavolok v Rimu, 313 - 315 (pogled na levo lice)

${ }^{21}$ O Konstantinovih pismih sasanidskemu kralju Saporju: Evzebij, Vita Constantini, IV, $9-13$.

${ }^{22}$ JONES, 1973, str. 95 - 96 . 
Triumphalis v Rimu leta 312 ali 313 in sicer v čast Konstantinove vojaške zmage nad Maksencijem v bitki pri Milvijskem mostu (28. oktobra 312) in ob priliki bližajoče se obletnice decennalia (25. julij 315). Slavolok obenem proslavlja diarhijo Konstantina in Licinija ter njuno složnost (concordia). ${ }^{23}$

Čeprav je bil Konstantinov slavolok zgrajen v 4. stoletju, da bi proslavil tedanje zgodovinske dogodke, je le del slavoločnega okrasa nastal sočasno. Večina reliefov in celo nekateri arhitekturni členi so spolije: izvirajo bodisi iz starejših spomenikov, ki so bili uničeni v požarih med leti 287 in 307 , bodisi so bili izbrani med neuporabljenimi deli spomenikov v cesarskih delavnicah.

Konstantinov slavolok ni prvi rimski spomenik, ki je uporabil spolia. Še več, zdi se celo, da je bila uporaba starejših arhitekturnih delov in figuralnih reliefov pri načrtovanju slavolokov v pozni antiki pravilo. Starejši primer je Dioklecijanov Arcus Novus, v katerega je ustanovitelj tetrarhije vključil dele starejšega Klavdijevega Britanskega slavoloka (Klavdijeva osvojitev Britanije se je namreč v času tetrarhov namreč ponovila); kasnejša sta Janusov monument iz 1. polovice 4. stoletja in t.i. Portugalski slavolok iz 5. stoletja.

\section{Concordia diarhov}

Iz nekega, še neidentificiranega, verjetno zasebnega Hadrijanovega spomenika izvira osem tondov na severni in južni strani slavoloka. Na severni stranici se tako zvrstijo naslednji prizori: Lov na merjasca, Žrtvovanje Apolonu, Lov na leva in Žrtvovanje Herkulu. Na južni stranici je sosledje podobno: Odhod na lov, Žrtvovanje Silvanu, Lov na medveda in Žrtvovanje Diani.

Glave protagonistov so se ohranile v petih od osmih medaljonov (od teh štiri na severnih tondih). Tako na severni strani Konstantin lovi merjasca in Licinij žrtvuje Apolonu, Konstantin zmaguje nad levom in Licinij žrtvuje Herkulu; na jugu Konstantin žrtvuje Diani in, če je shema dosledna, Licinij sodeluje v lovu na medveda, Konstantin žrtvuje Silvanu in Licinij odhaja na lov.

Enakovredna prisotnost obeh vladarjev v medaljonskem ciklu kaže na to, da je bilo eno izmed sporočil Konstantinovega slavoloka concordia diarhov. To sporočilo je bilo poudarjeno tudi grafično: vsak tondo je bil namreč obkrožen s porfirijem (marmorjem, ki so si ga izbrali tetrarhi) in tudi glavi Konstantina in Licinija sta bili v prizorih Lova na merjasca in leva ter Žrtvovanja Apolonu in Herkulu obdani $z$ avreolo. Ta je bila dodana v zgodnjem 4. stoletju ob menjavi portretnih poprsij.

${ }^{23}$ Galerijev slavolok v Solunu proslavlja tetrarhijo, Konstantinov v Rimu diarhijo. 


\section{Zmaga v državljanski vojni in ponovna uvedba »monarhije» po zgledu cesarjev 2. stoletja}

Iz časa Trajana so v Konstantinov slavolok vključeni naslednji reliefi:

(a) iz Velikega Trajanovega friza prihajajo:

- reliefa Trajanov adventus in Trajan na konju nad padlim Dačanom ob straneh centralnega loka; obe Trajanovi glavi sta ponovno izklesani kot Konstantinovi.

- dva prizora na atiki, ki prikazujeta spopad med rimskimi vojščaki in Dačani.

(b) kipi dačanskih ujetnikov na osmih stebrih slavoloka so verjetno iz Trajanovega foruma.

Iz izgubljenega slavoloka Marka Avrelija je v severno in južno stranico atike vključenih osem reliefov vertikalnega formata. Upodobljeni so prizori Adventus in Profectio, Liberalitas in Suppositio, Adlocutio in Lustratio, Rex datus in Captivi. Glave Marka Avrelija so bile v 4. stoletju zamenjane s podobami Konstantina, v modernih časih pa Trajana.

Preostali okras je sočasen postavitvi slavoloka. To skupino reliefov sestavljajo:

- Viktorije z geniji letnih časov v trikotnikih nad centralnim lokom na severni in južni strani;

- rečni bogovi nad manjšimi loki;

- sklepniki vrh lokov: na severni strani Mars in Roma Aeterna (zadnja figurica manjka); na južni Merkur, Quies ali Securitas Rei Publicae in Genius Populi Romani;

- baze stebrov, dekorirane $z$ Viktorijami in rimskimi vojščaki ali trofeje $\mathrm{z}$ barbarskimi ujetniki;

- tonda z motivoma Konstantina-Nepremagljivega Sonca (na vzhodnem delu slavoloka) in Lune (na zahodu). Izdelana sta bila $\mathrm{z}$ namenom, da bi zaokrožila cikel Hadrijanovih tondov. Izklesana sta bila v istem proporcu in obdana s porfirijem.

- figuralni friz, ki se prične v severo-zahodnem kotu slavoloka in ki obdaja celoten spomenik. Upodobljeni so naslednji prizori: Konstantinov odhod iz Milana, Zavzetje Verone, Bitka pri Milvijskem mostu, Cesarjev prihod v Rim, Nagovor rimskemu narodu in Largitio 1. januarja 313. Posamezne epizode so med seboj povezani s figurami rimskih vojščakov, ki so prikazani stoje ali na konju.

Figuralni friz je na slavolokih navadno tekel nad stebri, kot npr. na Titovem slavoloku v Rimu in na Trajanovem v Beneventu, in je navadno upodabljal triumfalni sprevod. Arhitekturna shema kasnejših slavolokov (poleg obravnavanega še slavolok Septimija Severa v Rimu) je s prostostoječimi stebri na visokih piedestalih onemogočala tradicionalno postavitev 
friza, ker bi bil tako nečitljiv. Zato je kontinuirani relief postavljen med loke in tonde; zaradi enovitosti sheme sta na krajših stranicah dodana medaljona Solis et Lunae. Namesto tradicionalne tematike triumfalne procesije (na slavoloku Septimija Severa jo najdemo), so vključeni zgodovinski in ceremonialni prizori. Obenem pa triumfalna procesija ni bila ravno najbolj primerna tematika, kajti zmage, ki jo slavolok proslavlja, Konstantin ni dosegel nad barbari, ampak v državljanski vojni. Zato se Konstantinov slavolok razlikuje od večine tovrstnih spomenikov; pravzaprav je njegov edini predhodnik Avgustov slavolok na Rimskem forumu po zmagi pri Akciju. Toda ta zmaga je bila ponazorjena kot zmaga nad Kleopatro in slavolok so kmalu podrli, da bi na istem mestu postavili novega na čast Avgustove zmage nad Parti.

Med epizodami figuralnega friza je v okviru tega, prvega pomenskega sklopa interpretacije Konstantinovega spomenika, najzgovornejši prizor Konstantinovega nagovora rimskemu narodu. Kraj nagovora je na kiparski upodobitvi določen ne le z natančno upodobitvijo rimskih rostra (ograja $z$ glavicami amorinov, kipa sedečih moških figur levo in desno), ampak je tudi topografsko označen s shematičnim posnetkom okoliških spomenikov: na levi arkade Bazilike Julijcev, sledi enoločni Tiberijev slavolok; na desni troločni Slavolok Septimija Severa; za rostraje nakazanih pet stebrov Spomenika decennalia s kipi Jupitra in genijev tetrarhov na vrhu. Stoječa frontalna figura Konstantina (ki je sedaj brez glave) je postavljena pred steber $\mathrm{z}$ Jupitrom. Oblečen je v vojaško obleko, sestavljeno iz kratke tunike in voluminoznega plašča. Obdan je s figurami senatorjev v togah, ki so tudi postavljeni frontalno, le da so njihove glave usmerjene proti imperatorju. Levo in desno je upodobljen rimski narod, ki ga predstavljajo moški in nekaj dečkov v tunikah. ${ }^{24}$ Postavljeni so frontalno, v dveh vrstah; v drugi vrsti so upodobljene le glave.

Podobi sedečih moških figur na levem in desnem robu govorniškega odra sta verjetno portreta Marka Avrelija (ozek obraz, kodrasti lasje, dolga brada) in Hadrijana (kodrasti lasje, krajša brada); predstavljata jasno ilustracijo Konstantinovega političnega programa. Konstantin se je namreč hotel razločiti od tetrarhov in se priličiti velikim vladarjem 2 . stoletja: Trajanu, Hadrijanu in Marku Avreliju. Konstantinova glava sicer manjka, toda po vsej verjetnosti je bil upodobljen kot novi Trajan (to dokazuje neoTrajanova frizura na njegovih številnih portretih po slavoloku), $v$ istem slogu kot ostala dva cesarja.

Ta prizor, v katerem je Konstantin postavljen v linijo 'dobrih cesarjev

${ }^{24}$ Vključitev moških potomcev v državni relief je tesno povezana s Konstantinom in njegovimi sinovi. Konstantin si je namreč prizadeval uveljaviti dedno nasledstvo, do česar je po njegovi smrti tudi prišlo, kajti njegovi trije sinovi, Konstantin II., Konstans in Konstancij II., so vladali od 337 do 361. 
2. stoletja', je obenem ključ za razumevanje izbire in vključitve starejših reliefov kot spolij v Konstantinov slavolok. Izbrani prizori niso bili v nov monument postavljeni naključno, ampak z namenom, da bi poudarili Konstantinovo razlikovanje od neposrednih predhodnikov in podobnost $z \mathrm{An}$ tonini.

\section{Sol Invictus Imperator - Tondo s Konstantinom-Nepremagljivim Soncem na kvadrigi}

Na vzhodnem tondu slavoloka je upodobljen Konstantin kot Sol Invictus, kako se na četverovpregi dviga nad morjem (personificira ga zleknjeni Okean); krilati Amor mu kaže pot s prižgano baklo. Sol Invictus Im-

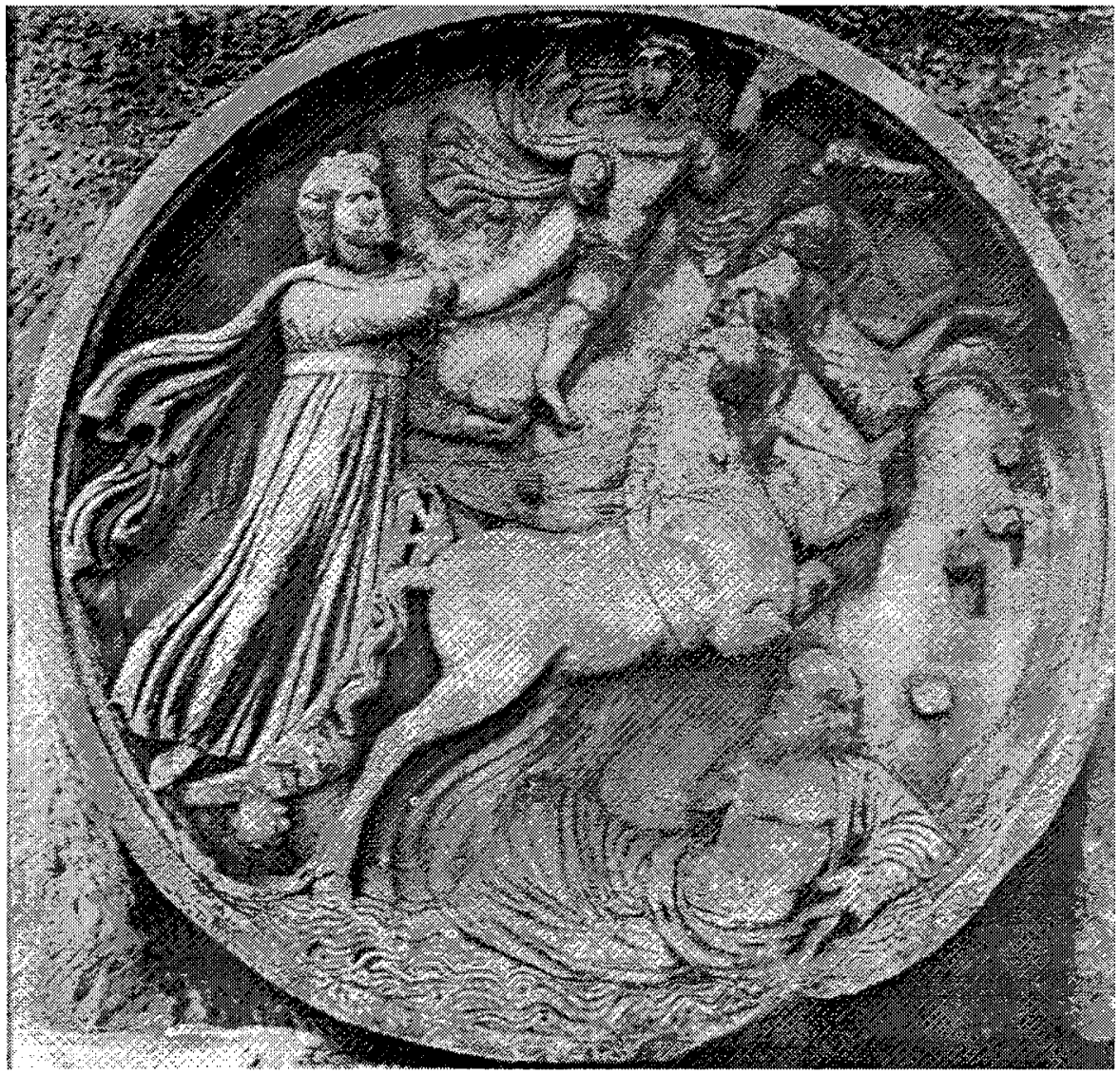

Slika 2: Konstantin na Sončevi četverovpregi; Tondo s Konstantinovega slavoloka v Rimu, 313 - 315 
perator drži v levici globus; desnica je dvignjena v magični gesti (magna manus).

Na zahodni stranici najdemo njegov pendant: medaljon $z$ Luno na spuščajoči se bigi, okrašeni $z$ motivom akantovja. Vajeti dvovprege drži v rokah Amor; smer potovanja je Okean.

Motiv Sonca in Lune, Heliosa in Selene, je na izdelkih rimske likovne umetnosti pogosto prisoten, ${ }^{2.5}$ obravnavanemu spomeniku pa so časovno najbližje naslednje kiparske dekoracije:

- sarkofag iz začetka 4. stoletja, ki je sedaj hranjen v rimskem Museo Capitolino; ${ }^{26}$

- številni reliefi z Mitro, ki ubija bika (Sol in Luna sta navadno prikazana v zgornjih kotih);

- patena iz Parabiaga, konec 4. stoletja (Milano, Civico Museo Archeologico);

- Arkadijev steber v Konstantinoplu (ok. 401 - 402): v zgornjem registru je ob Nikai, ki držijo klipej s križem, namesto tradicionalne ikonografije Sonca in Lune dvojna upodobitev Sončeve četverovprege. ${ }^{27}$

Motiv Sonca in Lune spada v okvir kozmične ikonografije. V tej dvojici Luna ohranja skozi čas tradicionalno tipologijo in vsebine, Sonce pa je doživelo številne premene, zlasti pod vplivom sinkretizma. Sprva je upodobljeno v pomenskem in ikonografskem kontekstu Sol-Helios-Apolon, toda pod vplivom vzhodnih Solarnih religij in zlasti od cesarjev Elagabala in Avrelijana dalje, se je njegova vloga v rimskem panteonu preoblikovala, zadobil je nov status vrhovnega božanstva, nove insignije in novo ime: Sol Invictus. Asociiranega s cesarjem po zgledu transfigurirane podobe in v sklopu kozmične ikonografije ga Hans Peter L'Orange ${ }^{28}$ imenuje Sol Invictus Imperator.

Razvoju ikonografije Sonca na četverovpregi moremo slediti preko upodobitev na novcih:

(a) Na bronastem medaljonu Antonina Pija stopa Sol, upodobljen v herojski goloti, s chlamys preko ramen, na kvadrigo. V levici drži uzdo, v

${ }^{25}$ npr. kiparski okras oklepa Avgusta iz Prima Porte (marmorna kopija originala iz brona, po 20 pr. Kr.; Vatikanski muzeji) in reliefi na efeškem oltarju Antoninov (169; Wien, Kunsthistorisches Museum)

${ }^{26} \mathrm{~V}$ isto skupino sarkofagov ( $z$ mitološko tematiko in obenem motivom Sonca in Lune) spadajo naslednji primerki: Sarkofag, izdelan med leti 190 in 210 (New York, Metropolitan Museum); Sarkofag iz 2. četrtine 3. stoletja (Roma, Galleria Doria Pamphilij); Sarkofag iz Woburn Abbey, ne pred 1. polovico 3. stoletja.

${ }^{27}$ MUSSO, 1983, str. 85: "Dvojno upodobitev Sončeve kvadrige moremo razumeti v okviru zgodovinskega konteksta, kajti sedaj je bil imperij razdeljen med Arkadija in Honorija. Sonce tako vlada nad obema. (...) V skladu z ideali Konstantina Velikega se je ohranila devotio Soncu kot cesarjevemu osebnemu patronu in zaščitniku njegove družine."

${ }^{28}$ L'ORANGE 1973. 
spuščeni desnici flagellum. (Pod kvadrigo je zleknjena Ge, spredaj stopa Phosphoros.)

(b) Na bronastem medaljonu Komodija je Sol prikazan po prejšnji tipologiji, le da je pridana žarkovna krona.

(c) Na zlatniku Septimija Severa stopa Sol radiatus na kočijo; v levici je uzda, desnica je dvignjena (magna manus).

(d) Zlatnik Karakale prinaša Sol radiatus na kvadrigi; v levici bič, desnica je dvignjena.

(e) Na bronastem medaljonu Avrelijana najdemo božanstvo Sol v herojski goloti, s chlamys preko ramen, na kvadrigi; v levici drži globus, desnica je tudi tu dvignjena.

(f) Na folisu Maksimiana je Sol radiatus upodobljen na kvadrigi frontalno. Oblečen je v dolgo tuniko in plašč; v levici globus, desnica dvignjena, na robu napis SOL INVICTUS.

Sol-Helios-Apolon, v sinkretizmu s sirskim Sol Invictus, je imel v Konstantinovi ideologiji in posledično ikonografiji že od samih začetkov vodilno vlogo. Navezavo in poistovetenje cesarja $\mathrm{z}$ vrhovnim sončnim božanstvom so propagirali tako pisni kot likovni spomeniki.

$V$ enem izmed številnih panegirikov ${ }^{29}$ na čast Konstantina pesnik opeva vizijo ali epifanijo Apolona, ki se je Konstantinu dogodila v bližini Marseillesa. V drugem slavilnem spisu ${ }^{30}$ avtor Konstantina direktno primerja s Soncem in ga celo locira na Sončevo kvadrigo: »O felix imperio et post imperium felicior, dive Constanti, quem curru paene conspicuo, dum vicinos ortus repetit occasu, Sol ipse invecturus caelo excepit. «

Konstantin je prikazan kot Sol Invictus na bronenem kipcu iz Kopenhagena (Kopenhagen, Nationalmuseum); žarkovna krona in magna manus sta nezmotljiva indica identifikacije s tem sirskim bogom. Na medaljonu iz leta 313, ki je sočasen izgradnji slavoloka, je Sol Invictus upodobljen kot Konstantinov alter ego: sončno božanstvo je postavljeno v profilu za Konstantinom, ki drži v rokah ščit, okrašen s Sončevo četverovprego. Sol Invictus je Konstantinov comes na novcih iz Triera, kjer je bil sprva Konstantinov sedež, in Londona. Na kameji iz katedrale v Camminu gre za nekoliko bolj generično asimilacijo Konstantina s Heliosom. In končno, vsi Konstantinovi kolosi, tudi tisti, katerim so bile kasneje pridana krščanska znamenja, spadajo v okvir Sončeve ikonografije. Zlasti dva in sicer prva verzija kolosalnega marmornega kipa Konstantina v absidi Basilike Nove (Maksencijeva-Konstantinova bazilika na Rimskem forumu, ki jo je Konstantin ponovno posvetil leta 313) in kolos Konstantina-Apolona na forumu v Konstantinoplu nosita izključno poganske konotacije.

Sol Invictus se v kiparskem okrasu Konstantinovega slavoloka, poleg

2: Paneg. Lat., 4, 2

3) Paneg. Lat., 4, 14 
poistovetenja $\mathrm{z}$ vladarjem $\mathrm{v}$ motivu Sol Invictus Imperator, pojavi še dvakrat samostojno in sicer:

- na bazah stebrov so na reliefih iz časa Konstantina upodobljeni rimski vojščaki, ki nosijo kipe Nepremagljivega Sonca;

- podobne kipe zasledimo na frizu v prizoru Konstantinovega whoda $\mathrm{v}$ Rim.

\section{Soobstoj in preplet ikonografije Nepremagljivega Sonca in krščanske simbolike ali Konstantin kot prvi krščanski in obenem zadnji poganski cesar}

Kip Konstantina-Apolona na forumu v Konstantinoplu dokazuje tesno navezanost cesarja na kult boga Sonca do konca njegovega življenja, čeprav je trdno verjel, da je krščanski Bog tisti, ki ščiti Rim in usodo imperija. Konstantin je pogosto asociiral krščanskega Boga z Nepremagljivim Soncem; to izpričuje že sama pripoved o Konstantinovi spreobrnitvi, ko je nad Soncem zagledal znamenje križa. Obenem je Kristus v tedanjih spisih pogosto imenovan kot Sol Salutis in Sol Iustitiae. Zato je Evzebij ${ }^{31}$ brez pomislekov primerjal vladarja s Soncem in zapisal: "Kot vzhaja Sonce nad zemljo in daje obilno vsem ljudem sijaj svoje luči, tako se tudi Konstantin, $\mathrm{v}$ popolni sinhroniji $\mathrm{z}$ nebeško zvezdo, ob sončnem vzhodu pojavi pred cesarsko palačo in s svetlečimi žarki svoje kreposti osvetljuje vse, ki se predstavijo pred njegovim obličjem.«

Med Konstantinom kot zadnjim poganskim in prvim krščanskim vladarjem ne moremo potegniti jasne razmejitvene črte, kajti v njegovem času sta se poganski Solarni simbolizem in krščanstvo prepletala. O tem pričajo številni Konstantinovi spomeniki, ki so ambivalentnega značaja ali pa omogočajo na ideološko-religiozni ravni večpomensko branje, ki zadovolji tako poganskega kot krščanskega gledalca.

Tekst dedikacijskega napisa, ki se ponovi na severni in južni strani atike Konstantinovega slavoloka, se glasi:

IMP. CAES. FL. CONSTANTINO MAXIMO

P. F. AVGVSTO S. P. Q. R.

QVOD INSTINCTV DIVINITATIS MENTIS

MAGNITVDINE CVM EXERCITV SVO

TAM DE TYRANNO QVAM DE OMNI EIVS

FACTIONE VNO TEMPORE IVSTIS

REPVBLICAM VLTVS EST ARMIS

ARCVM THRIVMPHIA INSIGNEM DICAVIT.

${ }^{31}$ Evzebij, Vita Constantini, XLIII, 3 
Instinctu divinitatis je na napisu generična oznaka za 'znamenje božanstva' in 'božji poseg', ki se je dogodil pri Milvijskem mostu, in mogli bi trditi, da je slavolok poganski spomenik z morebitnimi aluzijami na krščanstvo. Morda tudi zato, ker je bil rimski senat, ki je dal spomenik postaviti, žarišče rimske izobražene aristokracije, ki se je še dolgo držala poganskega neoplatonističnega monoteizma.

Med Konstantinovimi kolosi so ohranjena pričevanja zlasti o treh monumentalnih portretih tega tipa; ti so značilni primeri, ki omogočajo večplastno branje:

- V drugi verziji kolosalnega marmornega kipa, ki je bila izdelana okoli 315 - 330 (Roma, Palazzo dei Conservatori) in postavljena v absido Basi-

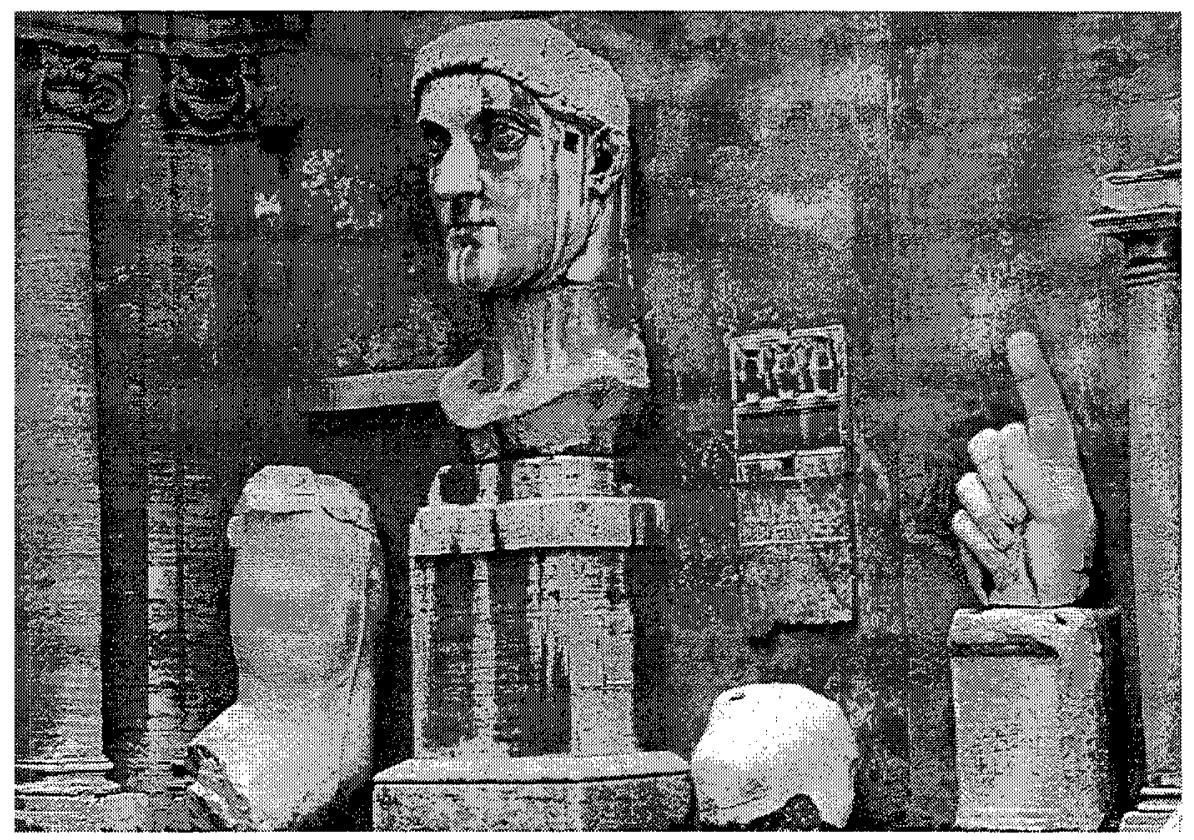

Slika 3: Preostali deli marmornega kolosa Konstantina Velikega;

Roma, Palazzo dei Conservatori

like Nove, je bil Konstantin verjetno upodobljen v pozi Jupitra. Ohranjeni deli so izdelani v različnih marmorjih, draperija je bila verjetno bronena. Cesar je po vsej verjetnosti držal v rokah žezlo s križem, kot ga je opisal Evzebij. Ker sta bili najdeni dve desnici, obe v tesni navezavi s kolosom, je možno, da so desnico $z$ navadnim žezlom (prva verzija tega istega kipa) zamenjali s krščansko ikonografijo.

- Od bronenega kolosa Konstantina, ${ }^{32}$ izdelanega med leti 336 in 337

${ }_{32}$ Pri tem kolosu identifikacija ni povsem jasna; po mnenju nakaterih gre za portret Konstancija II. 
(Roma, Palazzo dei Conservatori), se je ohranilo le portretno poprsje. V letu 1200 je izpričan pred Lateransko palačo v Rimu, toda o njegovi antični lokaciji ni nič znanega.

- V Konstantinoplu je sredi mesta stal cirkularni Konstantinov forum, v center katerega je dal Konstantin na stebru iz porfirija postaviti svoj kolosalni portret v ikonografiji Sol-Helios-Apolon.

Po mnenju Diane E.E. Kleiner ${ }^{33}$ najdemo na novcih štiri tipe portretov Konstantina Velikega; v nobenem pa ne zasledimo čiste krščanske simbolike:

1) tip Konstantina tetrarha, npr. na Konstantinovem srebrniku iz let 306 - 307, ki je najzgodnejši Konstantinov identificiran portret.

2) tip Konstantina kot neo-Avgusta ali s Trajanovo frizuro, npr. na Konstantinovem solidu iz leta 313.

3) tip Sol Invictus: na medaljonu, izdanem v Ticinu leta 313, je vladar upodobljen z oklepom, sulico in ščitom s Sončevo četverovprego. Za njim stopa Sonce z žarkasto krono kot Konstantinov comes. Legenda se glasi INVICTVS CONSTANTINVS. Konstantin ima poudarjeno dvignjeno desnico (magna manus).

4) spoj poganske in krščanske ikonografije: Na miliarensisu s frontalnim portertom Konstantina (verjetno iz Rima, ok. 315) je prikazan Konstantin v oklepu in kot general s konjem. Na čeladi je izpisan emblem chirho, v rokah drži žezlo $z$ znamenjem križa, toda na ščitu je še vedno volkulja $z$ Romulom in Remom.

Celo Konstantinopel, zadnja Konstantinova veličastna umetnina, ni bil zamišljen kot izključno krščanski, ampak kot spoj starega in novega. Konstantin je tako istočasno posvetil kip Tyche kot pendant rimske Fortune (ali Rome) ${ }^{34}$ postavil svoj monumentalni portret $v$ tipu Apolona in obenem izdal naročilo za kipe Kristusa in dvanajsterih apostolov ter svojo palačo okrasil z mozaikom z motiviko križa.

\section{Konstantinova konsekracija}

Konstantin je tik pred smrtjo kronal svojo spreobrnitev s krstom in kmalu zatem, na binkošti leta 337, umrl. Evzebij ${ }^{35}$ je ohranil pričevanje o njegovem pogrebu:

"Ko je prišel drugi od njegovih sinov, je sprejel odločitev, da se bo očetov pogreb obhajal javno, in se sam postavil na čelo pogrebnega spre-

\footnotetext{
33 KLEINER, 1992, str. 434.

${ }^{34} \mathrm{Na}$ novcih je prikazana kot ženska personifikacija s corona turrita; $\mathrm{v}$ roki ima cormucopia, nogo pa naslanja na ladjin premec.

35 Evzebij, Vita Constantini, IV, $70-71$
} 
voda. Prvi so se pomikali vojaki, postrojeni v strnjene čete, sledila je brezštevilna ljudska množica; telo vladarja so obdajali suličarji in hopliti. Ko so dospeli do cerkve Svetih Apostolov, so nosilnico položili na tla. Tako je novi cesar Konstancij počastil svojega očeta tudi s svojo lastno prisotnostjo in izvršil dolžnosti sinovske pietete.

Ko se je $z$ vsemi vojaki umaknil, so se približali duhovniki $z$ velikansko množico verujočih in pričeli z molitvami in obredom svete maše. Sveti cesar je ležal v svetišču na visokem katafalku in obhajanje tega obreda je potekalo njemu na čast. Velika množica ljudi je skupaj z duhovniki, med tožbami in ne brez solza, povzdignila h Gospodu molitve za vladarjevo dušo in s tem izpolnjevala voljo samega cesarja, ki ga je Bog ljubil. In še enkrat se je izkazalo božje usmiljenje do njegovega služabnika, kajti njegova smrt je njegovim predragim, zakonitim naslednikom naklonila cesarsko oblast, njemu samemu pa dala to čast, da je njegova oseba na kraju, ki si ga je sam izbral, evocirala spomin na apostole. Tako je še danes moč videti telo te duše, ki je bila trikrat blagoslovljena, glorificirano ob imenu apostolov in obdano z Božjim ljudstvom, v centru svetih ceremonij in mistične skrivnosti, deležno svetih molitev in tudi po smrti ohranjajoč cesarsko dostojanstvo. «

Konstantin je že za časa življenja dal natančna navodila, kam naj ga pokopljejo. V cerkev Svetih Apostolov je dal postaviti dvanajst kenotafov, po šest na vsaki strani. V centru je bil sarkofag namenjen njemu, cesarju » isoapostolu (ali trinajstemu apostolu) in škofu univerzuma». ${ }^{36}$ Obenem pa je vse do smrti, vsaj formalno, ohranil naziv in funkcijo pontifexa maxi$m a$, vrhovnega svečenika poganske religije. Novec, ki je bil izdan ob konsekraciji (Sl. 4), ${ }^{37}$ je izredno zgovoren in kaže na to, kako se je poganska tradicija, ki je predvidevala divinizacijo pokojnega cesarja, preoblikovala $z$ nastopom krščanstva. Evzebij ${ }^{38}$ je motiv opisal s temi besedami:

"Bili so izdani tudi novci s podobo svetega cesarja capite velato na sprednji strani, na zadnji strani pa je bil upodobljen na četverovpregi v trenutku (aktu), ko ga na nebo sprejema (povzdigne) roka z neba."

Konstantinov novec moremo primerjati $z$ medaljonom, ki je bil izdan ob konsekraciji Konstantinovega očeta Konstancija Hlora leta $307^{39}$ in ki je obenem zadnja numizmatična upodobitev ob priliki konsekracije s pogansko simboliko. Medaljon je sinteza obeh tipov, s katerimi so na rimskih cesarskih novcih zaznamovali konsekracijo. Tako sta upodobljena bodisi

MARCONE, 2000, str. 104.

${ }^{37}$ Novci so bili najprej izdani v kovnici v Lugdunu, kasneje po celotnem imperiju. Hans Peter L'Orange (L'ORANGE, 1973, str. 334) je objavil še en novec drugega tipa, ki naj bi bil prav tako izdan ob priliki konsekracije Konstantina Velikega leta 337; tu je upodobljena pogrebna pyra.

${ }^{38}$ Evzebij, Vita Constantini, IV, 73

COHEN, 1888, str. 61, n. $26-28$. 


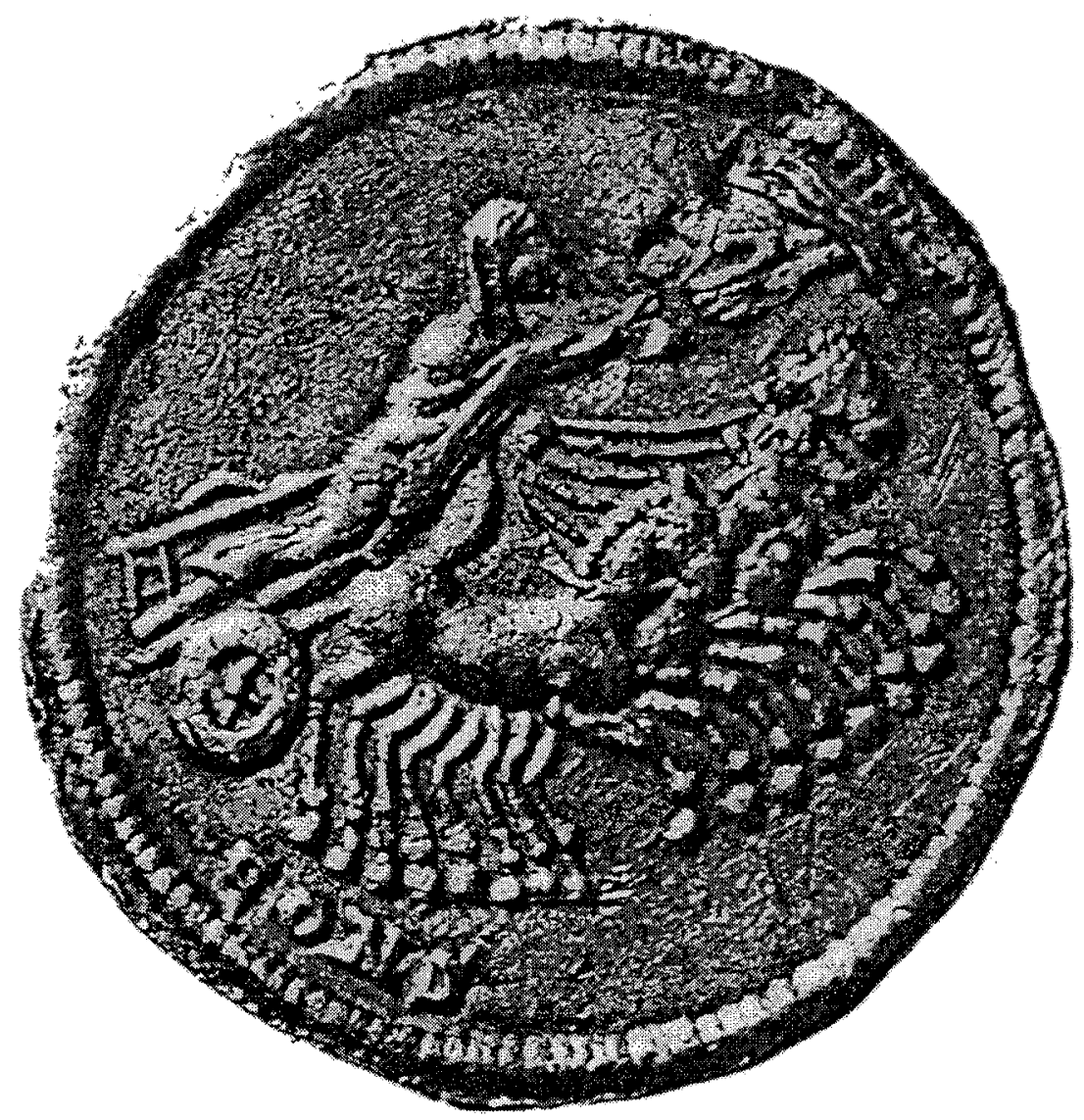

Slika 4: Konstantinova ascensio na četverovpregi;

Novec ob Konstantinovi konsekraciji

pyra $\mathrm{v}$ štirih nadstropjih bodisi Konstancij Hlor z žarkovno krono na psihopompu Sončevi kvadrigi.

Že ob bežnem pogledu na predstavljena kovanca je jasno, da se je koncept cesarjevega povzdignjenja v nebo spremenil. Psihopomp sam po sebi ne zadošča več in cesar ne bo po smrti stopil kot novo božanstvo med uradne bogove rimskega panteona. Konstantin je bil sicer za časa življenja deležen najvišjih časti, prav takih ali mogoče še večjih, kot so jih bili deležni njegovi poganski predhodniki. Tudi ob smrti je njegov status izjemen, saj je priznan celo za trinajstega apostola, kar je v zboru krščanskih svetnikov najvišja čast. Toda krščanstvo izpoveduje vero v enega samega, najvišjega Boga, ki vlada univerzumu in tudi prehod krščanske duše v nebesne sfere je možen le po milosti Božji. Zato cesarja, ki je v času svojega zemskega življenja izpolnjeval božjo voljo, sprejme v nebesa Božja roka (manus Dei). 


\section{BIBLIOGRAFIJA}

BECKWITH, J.: The Art of Constantinople: An Introduction to Byzantine Art (330-1453). London, 1961.

BENJAMIN, C.: Constantinus der Grosse. PW IV/1, 1013 - 1026.

BERENSON, B.: The Arch of Constantine and the Decline of Form. New York, 1954.

BEURLIER, E.: Le culte imperial, son histoire et son organisation depuis Auguste jusqu'a Justinien. Paris, 1891.

BIANCHI BANDINELLI, R.: La fin de l'art antique. Paris, 1970.

CERFAUX, L.-TONDRIAU, J.: Un Concurrent du Christianisme: Le culte des Souverains dans la civilisation greco-romaine. Tournai, 1957.

COHEN, H.: Description historique des monnaies: Médailles Imperiales V. Paris, 1888.

ELSNER, J.: Art and the Roman Viewer: The Transformation of Art from the Pagan World to Christianity. Cambridge, 1995.

ELSNER, J.: Imperial Rome and Christian Triumph: The Art of the Roman Empire $A D$ 100-450. Oxford, 1998.

HALSBERGHE, H.G.: The Cult of Sol Invictus. Leiden, 1972.

IACOPI, I.: L'Arco di Costantino. Roma, 1977.

JONES, A.H.M.: The Late Roman Empire 284 - 602: A Social, Economic and Administrative Survey I-II. Oxford, 1973.

KENT, J.P.C.-OVERBECK, B.-STYLOW, A.U.: Die römische Münze. München, 1973.

KLEINER, D.E.E.: Roman Sculpture. New Haven - London, 1992.

L'ORANGE, H.P.: Art Forms and Civic Life in the Late Roman Empire. Princeton, 1965.

L'ORANGE, H.P.: Likeness and Icon: Selected Studies in Classical and Early Medieval Art. Odense, 1973.

L'ORANGE, H.P.: Das spätantike Herrscherbild von Diocletian bis zu den Konstantin-Söhnen (284 - 361 p. Ch.). Berlin, 1984.

MacCORMACK, S.: Art and Ceremony in Late Antiquity. UCLA Press, 1981.

MANSUELLI, G.A.: La fine del mondo antico. Torino, 1988.

MARCONE, A.: Constantino il Grande. Roma - Bari, 2000.

MAZZARINO, S.: L'impero romano I - III. Roma - Bari, 1973.

MAZZARINO, S.: Antico, tardoantico ed era constantiniana I - II. Bari, 1974.

MUSSO, L.: Manufattura suntuaria e committenza pagana nella Roma del $\mathrm{N}$ secolo: Indagine sulla lanx di Parabiago. Roma, 1983.

TEJA, R.: Imperatore divino, imperatore cristiano. Storia di Roma III/1, 601 648.

RICHARDSON, jn., L.: The Date and Programe of the Arch of Constantine. Archeologia classica 27 (1975), 72 - 78. 
RUYSSCHAERT, J.: Essai d'interpretation synthetique de l'arc de Constantin. Atti della Pontificia Accademia romana di archeologia: Rendiconti 35 (1962 - 1963), 79 - 100.

VOGT, J.: Constantinus der Grosse. RAC III, 306 - 379.

\section{The Constantine's Arch and the Decline of the Roman Ruler Cult}

\section{Summary}

With Diocletian, who introduced the dominate, emperor took the title dominus et deus. From then on he rarely appeared in public, only within the framework of precisely ideal ceremonials and surrounded with an aura of holiness. After Constantine's conversion, the ruler cult in a form of pagan honores was gradually abolished, although the veneration of the emperor's person did not essentially change. Emperor and all those connected to him became holy and godlike.

The iconography of monuments shows that Constantine the Great, who before his conversion worshipped the Invictible Sun (Sol Invictus), after the victory at Milvius Bridge also more or less associated Christ with the Sun God. Many Constantine monuments are of an ambivalent character or allow more than one interpretation at an ideological level, that satisfies both pagan and Christian observers. At Constantins consecration, however, a coin was minted with the emperor's ascensio on a four-horse carriage and with a hand from the heavens extended towards him. Constantine attained the highest honour during his lifetime (as great or greater than that enjoyed by his pagan predecessors) and also had an exceptional status at death as he is also known as the 13th apostle. Christianity, however, declares there is only one god, the highest God that rules the universe, and the transfer of the Christian soul and also emperor's to heaven is dependent on God's mercy alone. During his life on earth, therefore, emperor fulfils God's will and is accepted into heaven by God's hand (manus Dei).

Naslov:

mag. Monika Osvald

Univerza v Ljubljani, Filozofska fakulteta

Aškerčeva 2

SI-1000 Ljubljana

e-mail: m_osvald@hotmail.com 